mgr Violetta Perzyńska

Akademia Wychowania Fizycznego w Warszawie

Biblioteka Główna im. Jędrzeja Śniadeckiego

violetta.perzynska@awf.edu.pl

\title{
CZY POZYSKIWANIE ZEWNĘTRZNYCH ŹRÓDEŁ FINANSOWANIA BIBLIOTEKI TO SZANSA NA JEJ ROZWÓJ?
}

\author{
IS THE ACQUISITION OF THE EXTERNAL FINANCING \\ AN OPPORTUNITY FOR THE LIBRARY DEVELOPMENT?
}

\begin{abstract}
Abstrakt
Celem artykułu jest przekazanie praktycznych informacji na temat skuteczności biblioteki w pozyskiwaniu środków zewnętrznych. Aktywność i samodzielność biblioteki w zakresie pozyskiwania funduszy na rozwój powinna być pozytywnie postrzegana przez środowisko akademickie. Czy tak jest? W referacie autorka podejmie próbę odpowiedzi na to pytanie. Omawia także praktyczne problemy związane z pozyskiwaniem i rozliczeniami grantów oraz promocją nowych aktywności w środowisku akademickim. $\mathrm{Na}$ potrzeby niniejszego opracowania dokonano analizy podstaw prawnych w zakresie możliwości pozyskania środków przez biblioteki naukowe, oraz przeglądu stron WWW bibliotek uczelni wyższych. Dokonano analizy zamieszczonych przez biblioteki informacji o pozyskanych przez nie środkach finansowych. W dobie komercjalizacji wiedzy biblioteka musi być aktywna w pozyskiwaniu środków finansowych. Dobrym kierunkiem jest włączanie bibliotekarzy w zespoły projektowe powoływane w uczelni. Współpraca w tym zakresie integruje bibliotekarzy ze społecznością akademicką, pozwala szybciej dostosować się do zachodzących zmian.
\end{abstract}

Słowa kluczowe: biblioteki akademickie, fundusze bibliotek, fundusze strukturalne, programy operacyjne. 


\begin{abstract}
The aim of the article is to provide practical information on the effectiveness of a library in the obtaining external funds. The activity and the independence of a library in terms of raising funds for the development should be perceived positively by the academic community. Is it, though? In the paper, the author will try to answer this question. Also, she shares practical knowledge about the problems associated with the acquisition and the settlement of the grants as well as with the promotion of the new activities in the academic environment. For the purpose of this study, an analysis of the legal basis regarding the possibility of obtaining funds by the scientific libraries and a review of university libraries' websites were made. The libraries made an analysis of the information about the obtained funds and published it. In the age of the knowledge commercialization a library must be active in acquiring financial resources. The right direction is to involve the librarians in the project teams set up at the university. The cooperation in this area integrates the librarians with the academic community and allows for faster adaptation to changes.
\end{abstract}

Keywords: university libraries, library funds, structural funds, operational programs.

\title{
Pozyskiwanie środków finansowych - podstawy prawne
}

Pozyskiwanie środków finansowych na realizację zadań bibliotecznych nie jest zjawiskiem nowym. Tego rodzaju aktywność na stałe wpisała się w obszary działań bibliotek wszystkich typów. Biblioteki uczelniane podlegają Ustawie Prawo o szkolnictwie wyższym, w której w art. 13.1. wskazuje się m.in., że: „Podstawowymi zadaniami uczelni, z zastrzeżeniem ust. 2 i 3, są: [...] 5. upowszechnianie i pomnażanie osiągnięć nauki, kultury narodowej i techniki, w tym poprzez gromadzenie i udostępnianie zbiorów bibliotecznych i informacyjnych"1. Natomiast w art. 88.1 jest zapis mówiący o tym, że: „W uczelni działa system biblioteczno-informacyjny, którego podstawę stanowi biblioteka. Organizację i funkcjonowanie systemu biblioteczno-informacyjnego uczelni, w tym zasady korzystania z niego przez osoby niebędące pracownikami, doktorantami lub studentami uczelni, określa statut" W art. 92 zapisano: „Działalność uczelni publicznej jest finansowana $\mathrm{z}$ dotacji z budżetu państwa na zadania ustawowo określone oraz może być

1 Ustawa Prawo o szkolnictwie wyższym z dnia 27 lipca 2005 r. Dz.U. 2005, nr 164, poz. 1365 z późn. zm., s. 9.

2 Tamże, s. 46. 
finansowana z przychodów własnych"3. Co oznacza wprost, że obowiązek ten spoczywa na uczelni.

Kolejnym dokumentem, który wpływa na możliwości aplikowania o środki jest Rozporządzenie Ministra Nauki i Szkolnictwa Wyższego w sprawie kryteriów i trybu przyznawania oraz rozliczania środków finansowych na działalność upowszechniająca naukę . Ścieżka do pozyskiwania dotacji na zadania związane $\mathrm{z}$ upowszechnianiem nauki pojawiła się wraz z powołaniem Ustawy z 30 kwietnia 2010 r. o zasadach finansowania nauki ${ }^{5}$ Narodowego Centrum Nauki (NCN), które jest organem pomocniczym Ministra Nauki i Szkolnictwa Wyższego (MNiSW). Do zadań NCN należy podział funduszy na badania naukowe. Kolejne nowelizacje Ustawy zredukowały do minimum możliwość pozyskiwania środków przez biblioteki uczelniane. Obecnie przewiduje ona dla bibliotek naukowych możliwość ubiegania się o finansowanie wyłącznie na cele związane z: utrzymaniem unikatowych w skali kraju zasobów bibliotecznych o istotnym znaczeniu dla nauki lub jej dziedzictwa, opracowywaniem naukowych zasobów bibliotecznych, udostępnianiem zasobów bibliotecznych w formie elektronicznej. Od tej reguły są pewne odstępstwa. Analizy stron domowych bibliotek dostarczają dowodów, że biblioteki uczelniane otrzymują środki także na implementację systemu bibliotecznego ${ }^{6}$. Zwykle są to jednak przedsięwzięcia ponadlokalne. Pewnym odstępstwem od tej reguły są opisane w „Przeglądzie Bibliotecznym" przykłady dofinansowania zadań w ramach programu DUN (Dotacja na Upowszechnianie Nauki) takich jak: reklama, promocja osobista, public relations ${ }^{7}$. $Z$ całą pewnością są to ważne zadania, trudno je jednak uznać za związane $\mathrm{z}$ opracowaniem i upowszechnianiem zasobów naukowych.

O środki z MNiSW biblioteki uczelni wyższych nie mogą aplikować samodzielnie. Problem, jaki może z tego powodu zaistnieć już w 2013 r. zdiagnozował m.in. dr hab. Artur Jazdon, który w swojej publikacji poświę-

3 Tamże, s. 48.

4 Rozporzadzenie Ministra Nauki i Szkolnictwa Wyższego w sprawie kryteriów i trybu przyznawania oraz rozliczania środków finansowych na działalność upowszechniajaca naukę. Dz.U. 2010, nr 179, poz. 1206.

5 Ustawa z dnia 30 kwietnia 2010 r. o zasadach finansowania nauki. Dz.U. 2010, nr 96, poz. 615 , s. 17.

6 Informacja pochodzi ze szkolenia zorganizowanego przez Centrum NUKAT w 2015 r., podczas którego zaprezentowano system Koha. Implementację systemu przeprowadzono dzięki finansowaniu zadania ze środków DUN.

7 M. Korczyńska-Derkacz: Nowe projekty, cenne inicjatywy i ciekawe przedsięwzięcia bibliotek naukowych. VIII Konferencja Korporacji Bibliotekarzy Wrocławskich (Wrocław, 2 grudnia 2016 r.). „Przegląd Biblioteczny” 2017, z. 1, s. 76. 
cił wiele uwagi tematowi pozyskiwania funduszy ${ }^{8}$. Zwrócił on m.in. uwagę na brak możliwości finansowania zadań Biblioteki Głównej z dotacji na działalność statutową.

W kontekście przywołanej Ustawy należy także zwrócić uwagę na fakt, iż ranking uczelni wyższych przekłada się na nierówne szanse bibliotek w aplikowaniu o dotację. Biblioteki akademii wychowania fizycznego nie są w stanie konkurować o nią z bibliotekami medycznymi, uniwersyteckimi czy politechnicznymi. W 2014 r. odmówiono Bibliotece Głównej Akademii Wychowania Fizycznego w Warszawie (BG AWF) przyznania dotacji celowej na dofinansowanie zadania inwestycyjnego pod nazwą: Zintegrowany system biblioteczny do zarzadzania zasobami informacyjnymi Biblioteki Głównej AWF Warszawa, argumentując decyzję następująco: „Biorąc pod uwagę kategorie naukowe wydziałów wchodzących w skład Uczelni [...], Zespół Specjalistyczny przyznał niski priorytet przedmiotowemu zadaniu inwestycyjnemu. [...] Wniosek został umieszczony w rankingu 131 wniosków na miejscu 100 i w związku z tym nie znalazł się na liście projektów rekomendowanych do dofinansowania"'.

Biblioteki uczelni wyższych widzą w źródle finansowania z DUN dużą szansę na realizację ważnych dla społeczeństwa zadań. Należy jednak pamiętać, że tego rodzaju środki powinny mieć charakter wspierający, a nie wyręczający uczelnię w finansowaniu zadań, do realizacji których ją powołano. Podstawowy dokument, który reguluje kwestie zarówno zadań biblioteki, jak i odpowiedzialność za zapewnienie środków na jej utrzymanie to Ustawa o bibliotekach ${ }^{10}$ Rozdział 1. Przepisy ogólne. Art. 4. Podstawowe zadania bibliotek. Natomiast art. $9^{11}$ określa obowiązki organizatora biblioteki.

Dodatkowo punktowane są wnioski, w których dobrze skalkulowano koszty zadań i uwzględniono co najmniej $20 \%$ wkładu własnego. Uczelnie, które mogą sobie pozwolić na zabezpieczenie dla bibliotek wkładu finansowego przyczyniają się do tego, że jednostka odnosi większe sukcesy w pozyskiwaniu dotacji.

8 Zob. A. Jazdon, M. Wojcińska: Zarządzanie finansami i pozyskiwanie funduszy. W: Bibliotekarstwo. Pod red. A. Tokarskiej. Warszawa 2013, s. 609.

9 Decyzja nr 19/N/DUN/2014 Ministra Nauki i Szkolnictwa Wyższego.

10 Ustawa z dnia 27 czerwca 1997 r. o bibliotekach. Dz.U. 2012, poz. 642 z późn. zm., s. 4.

11 Tamże, s. 4. 


\section{Aktywność bibliotek uczelni wyższych w zakresie pozyskiwania funduszy na realizację zadań w latach 2014-2016. Promocja sukcesu}

Potrzeba pozyskiwania dodatkowych środków na utrzymanie biblioteki jest oczywista. Nie jest tajemnicą, że z roku na rok uczelnie konsekwentnie obcinają środki na utrzymanie bibliotek. Dlatego pozyskiwanie dotacji zewnętrznej na realizację zadań wspierających rozwój polskiej nauki, to codzienność osób zarządzających biblioteką naukową. Zainteresowanie aplikowaniem o te środki rośnie, co zapewne wynika z coraz niższego wskaźnika sukcesu bibliotek innych niż uniwersyteckie. Nie tylko konkurencja jest znacząca, ale także coraz niższa pula środków, jakimi dysponuje Ministerstwo Nauki i Szkolnictwa Wyższego.

Biblioteka Główna im. Jędrzeja Śniadeckiego AWF w Warszawie w 2015 r. zrealizowała zadanie sfinansowane ze środków DUN pt.: Sport Polski - naukowa baza sportu polskiego ${ }^{12}$. Celem zadania była organizacja, budowa i uruchomienie ogólnodostępnej w Internecie bazy danych, popularyzującej informacje z zakresu sportu, wychowania fizycznego, rehabilitacji, turystyki i rekreacji. Realizacja projektu przysporzyła wiele problemów, które wynikały głównie z przyczyn zewnętrznych. Pierwszą barierą okazały się procedury związane z przetargami. Decydenci nie wyrazili zgody na to, aby zakup serwera oraz sprzętu komputerowego i skanera przeprowadzić oddzielnym przetargiem. W konsekwencji sprzęt, na którym miała pracować biblioteka, został zakupiony niemal po roku. W obawie przed opóźnieniami, podjęto decyzję o umieszczaniu danych na serwerze tymczasowym. Dostęp do darmowych serwerów niesie dodatkowe ryzyko utraty wprowadzonych danych. Atak hakerów nie ominął bazy. Niemal tysiąc rekordów mogłoby ulec zniszczeniu, gdyby nie przezorność programisty, który przewidział potrzebę beckupowania danych. Dodatkowe problemy wyniknęły z innych potrzeb uczelni i Biblioteki AWF. W wyniku prowadzenia procedur przez Centrum Informatyczne Biblioteka otrzymała gorszy sprzęt i była wyłączona z możliwości zadbania o skalkulowanie cen tak, aby były one zgodnie z umową podpisaną z MNiSW. Trzeba było zwrócić kilka tysięcy złotych do kasy DUN. Dużym problemem był także brak wsparcia pracowników administracyjnych. Problemy pojawiły się już na etapie przygotowania umów i nie zakończyły się na etapie rozliczania wniosku. Podobne problemy miała Biblioteka realizując zadanie, o które aplikowała z jednym z Wydziałów

12 Biblioteka Główna im. Jędrzeja Śniadeckiego AWF Warszawa. Tryb dostępu: http:// sportpolski.awf.edu.pl/ [27 maja 2017]. 
AWF. Do chwili obecnej nie udało się rozliczyć wniosku z powodu opieszałości działań administracji.

Determinacja bibliotekarzy, ich odpowiedzialność i pracowitość to w zasadzie największe źródło satysfakcji z realizacji projektu. Jak niewielkie są sukcesy Biblioteki AWF w aplikowaniu o środki widać, gdy porówna się je $\mathrm{z}$ sukcesami innych bibliotek. Przegląd dofinansowanych projektów, zamieszczonych na stronach domowych bibliotek uczelni wyższych, uwidacznia trendy $\mathrm{w}$ obszarze struktury finansowania zadań. Wśród liderów jest m.in. Biblioteka Uniwersytecka im. Jerzego Giedroycia ${ }^{13}$ oraz Biblioteka Uniwersytetu Wrocławskiego ${ }^{14}$, które aplikują o środki z dużym powodzeniem i często realizują więcej niż jeden projekt jednocześnie. Wnioski o znaczeniu ponadlokalnym oraz realizowane w partnerstwie mają większe szanse na pozyskanie finansowania ze środków MNiSW. W tym konkretnym przypadku jeszcze jeden czynnik był istotny - niekwestionowana wartość kolekcji, które wybrano do promocji, popularyzacji, o dużym znaczeniu dla nauki i jej dziedzictwa.

Pewnym odstępstwem od Ustawy o finansowaniu nauki jest przyznanie środków DUN Bibliotece Uniwersyteckiej KUL, która w 2016 r. uzyskała środki na „Uzupełnienie zasobu serii Corpus Christianorum”. Z Dotacji na Upowszechnianie Nauki sfinansowano zakup 52 woluminów publikacji Corpus Christianorum. Series Graeca i Corpus Christianorum Series Latina wydawanej przez belgijskie wydawnictwo Brepols ${ }^{15}$.

Większe szanse na pozyskanie dotacji zawsze miały biblioteki z wielowiekowymi zasobami. Do nich należy m.in. Biblioteka Główna Uniwersytetu Ekonomicznego we Wrocławiu ${ }^{16}$ czy Biblioteka Jagiellońska, która w swojej strukturze wydzieliła Oddział Projektów. W latach 2015-2016 otrzymała środki aż na trzy zadnia ${ }^{17}$. Niekwestionowanym liderem

13 Więcej: Biblioteka Uniwersytecka im. Jerzego Giedroycia w Białymstoku. Tryb dostępu: http://bg.uwb.edu.pl/?pid=Projekty [27 maja 2017].

14 Więcej: M. Szala: Transkrypcje, dawnych utworów muzycznych w Bibliotece Cyfrowej Uniwersytetu Wrocławskiego. Tryb dostępu: http://www.digitalizacja.pl/Marcin-Szala/ Transkrypcje-dawnych-utworow-muzycznych-w-Bibliotece-Cyfrowej-Uniwersytetu [27 maja 2017].

15 Więcej: strona Biblioteki Uniwersyteckiej Katolickiego Uniwersytetu Lubelskiego Jana Pawła II (KUL). Tryb dostępu: http://www.bu.kul.pl/aktualnosci,art_31452.html [27 maja 2017].

16 Więcej: Biblioteka Główna Uniwersytetu Ekonomicznego we Wrocławiu. Tryb dostępu: http://www.bg.ue.wroc.pl/ [27 maja 2017].

17 Więcej: Biblioteka Jagiellońska Uniwersytetu Jagiellońskiego. Tryb dostępu: http://www. bj.uj.edu.pl/dun-2015-2016 [27 maja 2017]. 
jest także Biblioteka Uniwersytecka w Warszawie (BUW). Prężnie działający Oddział Projektów Celowych i Funduszy Zewnętrznych BUW pozyskał $\mathrm{w}$ tym okresie dotację na realizację pięciu zadań ${ }^{18}$. $\mathrm{Z}$ tego strumienia finansowego skorzystała także Biblioteka Uniwersytecka w Toruniu, aby w latach 2016-2017 zrealizować trzy zadania ${ }^{19}$.

Zapewne można by długo wymieniać przykłady aktywności zarządzających biblioteką oraz bibliotekarzy zaangażowanych w realizację zadań finansowanych ze środków MNiSW. Jednak nawet pobieżny przegląd stron domowych bibliotek pozwala potwierdzić tezę, że wskaźnik sukcesu w pozyskiwaniu środków jest wyższy po stronie bibliotek dużych ośrodków uniwersyteckich. To one, dysponując odpowiednio licznym zespołem i możliwością zapewnienia wkładu własnego, mają przewagę nad innymi, próbującymi konkurować o te środki, bibliotekami.

\section{Promocja sukcesu}

Biblioteka uczelni wyższej jako instytucja ucząca się nadal nie jest postrzegana przez własne, a tym bardziej zewnętrzne środowisko jako miejsce atrakcyjne, pozwalające na realizację ambicji zawodowych czy pasji naukowo-badawczych. Tymczasem biblioteka daje duże szanse rozwoju. Możliwość pogłębiania wiedzy, publikowanie, poznawanie nowych technologii, nadążanie za potrzebami środowiska naukowego i coraz bardziej wymagających użytkowników jest faktem. Bibliotekarze coraz odważniej sięgają po środki na realizację ważnych celów, chętniej dzielą się wiedzą, publikują informacje o sukcesach, rozpowszechniają je w mediach. Promocja odbywa się głównie poprzez zamieszczanie artykułów naukowych w prasie fachowej lokalnej oraz na stronach domowych bibliotek i mediów społecznościowych. Chociaż zasięg promocji nie jest wielki, to jednak jest zauważalny. Nie należy oczekiwać, że społeczeństwo w najbliższych latach przestanie postrzegać bibliotekę jako miejsce spokojne i wygodne, w którym bibliotekarka ma czas na czytanie prasy. Biblioteka uczelniana mogłaby dynamiczniej się rozwijać, gdyby polityka państwa wiązała sukcesy naukowe z budowaniem solidnego zaplecza i szybkiego dostępu do informacji naukowej. Tak jednak nie jest. Dlatego wysiłki bibliotekarzy wciąż są zauważane tylko przez wąską grupę użytkowników.

18 Więcej: Biblioteka Uniwersytecka w Warszawie. Tryb dostępu: http://www.buw.uw.edu. pl/index.php?option=com_content\&task=view\&id=2041\&Itemid=272 [27 maja 2017].

19 Więcej: Biblioteka Uniwersyteckiej w Toruniu. Tryb dostępu: http://www.bu.umk.pl/ granty [27 maja 2017]. 


\section{Doświadczenie Biblioteki Głównej AWF Warszawa w aplikowaniu o środki z funduszy europejskich}

Centrum Projektów Europejskich (CPE) to kolejne miejsce, w którym biblioteki uczelni wyższych aplikują w celu pozyskania pozabudżetowych źródeł finansowania. Wiele uczelni wyższych oraz podległych im bibliotek już w 2005 r. sięgnęło po fundusze europejskie. Echo tego rodzaju aktywności odnajdujemy w literaturze fachowej ${ }^{20}$. Warto zauważyć jak elastycznie zareagowały biblioteki na niekorzystne zmiany zachodzące w podejściu do nowej sytuacji rynkowej i gospodarczej, zapobiegając ubożeniu bibliotek. „Praktyka gospodarki rynkowej w Polsce spowodowała narastanie problemu uzupełniania finansów bibliotek akademickich poprzez zdobywanie środków pozabudżetowych"21.

Pozyskiwanie funduszy ze środków europejskich nie jest proste. Świadczą o tym publikacje na łamach „Forum Akademickiego”, w których zwrócono uwagę na niski wskaźnik sukcesu dla Polski w pozyskiwaniu funduszy $\mathrm{w}$ programie operacyjnym Horyzont 202022. W programach obok badaczy i naukowców uczelni, aplikują przedstawiciele instytutów i przemysłu. Biblioteki uczelni wyższych nie mogą samodzielnie ubiegać się o te środki, jednak mogą współuczestniczyć w aplikowaniu poprzez współtworzenie wniosków.

W 2016 r. Biblioteka Główna AWF Warszawa po raz pierwszy złożyła do Centrum Projektów Europejskich wniosek o dofinansowanie projektu w ramach Programu Operacyjnego Wiedza Edukacja Rozwój (projekt wdrożeniowy), oś priorytetowa IV Innowacje społeczne $i$ wspótpraca ponadnarodowa, pod tytułem: $R D A$ - wdrożenie międzynarodowego standardu katalogowania jako element podnoszenia kwalifikacji zawodowych bibliotekarzy polskich. Projekt miał być realizowany $\mathrm{w}$ partnerstwie z Łotewską Biblioteką Narodową, Stowarzyszeniem Bibliotekarzy Polskich i firmą

20 Najlepiej opisany jest okres programowania 2007-2013. Na ten temat pisali m.in. D. Grygrowski: Biblioteki i pieniądze. Warszawa 2015, s. 202-206 oraz M. Wojcińska, D. Wojciński: Fundusze strukturalne dla bibliotek w okresie programowania 2007-2013. „Biblioteka” 2009, nr 13(22), s. 111-121. Tryb dostępu: http://pressto.amu.edu.pl/index. php/b/article/viewFile/190/134 [27 maja 2017].

21 E. Kołodziejczyk: Pozabudżetowe źródła finansowania bibliotek akademickich $w$ Polsce $i$ innych krajach gospodarki wolnorynkowej. Wybrane przykłady i próba porównania. W: Pozazawodowe zainteresowania bibliotekarzy. Badania, teorie, wizje. „Biuletyn EBIB” 2005, nr 6(67). Tryb dostępu: http://www.ebib.pl/2005/67/kolodziejczyk.php [27 maja 2017].

22 Z. Krasiński: Wciąż nas za mało. „Forum Akademickie” 2017, nr 4(281), s. 5. 
przygotowującą wniosek pod względem formalnym, odpowiedzialną także za skalkulowanie kosztów. Niestety projekt przepadł, ponieważ nie dość obszernie opisano, w jaki sposób będą prowadzone szkolenia. Kto składał wnioski o fundusze strukturalne wie, że należy ściśle przestrzegać wymogów formalnych. Przekroczenie dozwolonej liczby znaków jest równoznaczne $z$ odrzuceniem wniosku na etapie oceny formalnej. Można było jednak obejść tę barierę przez dodanie załącznika ze scenariuszem szkoleń. Jednak tego aplikujący z AWF Warszawa nie byli świadomi.

Biblioteka AWF Warszawa, zgodnie z procedurą złożyła Protest od negatywnej decyzji Centrum Projektów Europejskich. W odpowiedzi na Protest - CPE napisało, że wprawdzie częściowo zgadza się z argumentami użytymi w Proteście, ale podtrzymuje ocenę negatywną. $\mathrm{Z}$ uzasadniena użytego przez AWF Warszawa uczyniono zgrabny zarzut: „Ponadto z wniosku wynika, że Polska prędzej czy później musi wdrożyć nowy standard katalogowania, ponieważ jak wskazuje wnioskodawca »nieprzyjęcie standardu RDA w praktyce oznacza wykluczenie bibliotek polskich z możliwości współpracy z partnerami zagranicznymi oraz przepaść technologiczną i naukową w stosunku do europejskich instytucji kultury«. Trudno tę konieczność uznać za element motywowania, czy ograniczenia barier bibliotekarzy w udziale w pozaszkolnych formach kształcenia"23.

Biblioteka AWF po raz pierwszy aplikowała o sfinansowanie projektu na współpracę ponadnarodową. Pomimo wsparcia instytucji, która ma doświadczenie $\mathrm{w}$ aplikowaniu o tego rodzaju środki wniosek został odrzucony. Korzyścią było nawiązanie współpracy z Łotewską Biblioteką Narodową oraz zdobycie doświadczenia, które w przyszłości pozwoli skuteczniej aplikować o środki z funduszy europejskich.

\section{Przykłady aplikowania bibliotekarzy o środki na badania naukowe}

Udział polskich bibliotek naukowych w tego rodzaju projektach jest wciąż niewielki. Tymczasem są one najbardziej pożądane przez władze uczelni. Szansą na pozyskanie środków na badania naukowe jest Narodowy Program Rozwoju Humanistyki (NPRH). Program działa od 2011 r. Jego celem jest „uzupełnienie polskiego systemu grantowego o finansowanie projektów, na które nie można uzyskać środków z NCN, NCBiR i z funduszy europejskich. Są to projekty wieloletnie, trwające czasem kilka-

23 Pismo Państwowej Jednostki Budżetowej Centrum Projektów Europejskich nr WP.425.246.2017.5AES. z dnia 9 maja 2017 r., s. 2. 
naście i więcej lat, polegające na tworzeniu naukowych publikacji dokumentacyjnych, słownikowych, bibliograficznych, krytycznych wydań źródeł i utworów literackich oraz kompendiów wiedzy o charakterze syntetycznym i encyklopedycznym (moduł Dziedzictwo narodowe)"24. Największe sukcesy pozyskania dotacji na badania naukowe odnotowuje Biblioteka Główna Uniwersytetu Mikołaja Kopernika w Toruniu, która od wielu lat jest beneficjentem grantów badawczych. W ramach Narodowego Programu Rozwoju Humanistyki uzyskała w analizowanym okresie dwa granty badawcze ${ }^{25}$.

Ministerstwo Nauki i Szkolnictwa Wyższego ma w swojej ofercie konkursy na badania naukowe, o które mogliby się ubiegać pracownicy naukowi bibliotek uczelni wyższych. Do nich należą:

Program OPUS 13 - gdzie można aplikować o fundusze na projekty badawcze, w tym zakup lub wytworzenie aparatury naukowo-badawczej, niezbędnej do realizacji tych projektów. O grant mogą się ubiegać osoby $\mathrm{z}$ tytułem naukowym, mające udokumentowane doświadczenie w prowadzeniu badań naukowych oraz dobrze punktowane publikacje $\mathrm{z}$ danej dziedziny.

Program PRELUDIUM 13 - który jest przygotowany dla osób rozpoczynających karierę naukową, nieposiadających stopnia naukowego doktora. Mogą otrzymać grant na projekty badawcze.

Biblioteki uczelni wyższych z powodzeniem aplikują także o środki na badania z innych źródeł niż NCN. Do sukcesów należy uzyskanie środków z Centrum Polsko-Rosyjskiego Dialogu i Porozumienia. Z tego strumienia finansowego skorzystały BUW ${ }^{26}$ oraz Biblioteka Uczelni Łazarskiego ${ }^{27}$. Warto zatem wzorując się na tych przykładach dążyć do aplikowania o finansowanie zadań naukowych z tego źródła.

24 Narodowy Program Rozwoju Humanistyki. Tryb dostępu: http://www.nauka.gov.pl/ projekty-i-inicjatywy/narodowy-program-rozwoju-humanistyki.html [27 maja 2017].

25 Biblioteka Główna Uniwersytetu Mikołaja Kopernika w Toruniu. Projekty. Tryb dostępu: http://www.bu.umk.pl/granty. [27 maja 2017].

26 Biblioteka Uniwersytetu Warszawskiego. Tryb dostępu: http://www.buw.uw.edu.pl/index.php?option=com_content\&task=view\&id=2041\&Itemid=272 [17 maja 2017].

27 Centrum Polsko-Rosyjskiego Dialogu i Porozumienia. Tryb dostępu: http://www.cprdip.pl/konkursy,otwarty_konkurs,edycja_2016.html [17 maja 2017]. 


\section{Wnioski}

Biblioteki z dużą tradycją, zasobne, których personel jest liczny, a dyrektorzy są dysponentami środków finansowych są beneficjentami większości grantów. Im wyższa liczba etatów merytorycznych, tym łatwiej można wyłonić stałe zespoły, stanowiące dobre zaplecze, także administracyjne, których działalność jest ukierunkowana na przygotowanie wniosków aplikacyjnych.

Sukces łatwiej osiągnąć, gdy zadanie jest ponadlokalne i gdy aplikuje się o granty wspólnie z innymi instytucjami kultury lub bibliotekami.

Zarówno porażka jak i sukces biblioteki w pozyskiwaniu środków jest uzależniony od wielu czynników. Poprawne przygotowanie wniosku nie gwarantuje, że biblioteka otrzyma fundusze na realizację zadań. Zasady oceny wniosków są niejawne. Departament Nauki MNiSW często wskazuje nie konkretny paragraf ustawy, tylko przywołuje całą ustawę jako podstawę do odrzucenia wniosku.

W bibliotekach, w których dyrektorzy nie są dysponentami środków finansowych i mają ograniczone budżety oraz niewielką liczbę etatów, dużym problemem jest także niepewność co do zapewnienia prawidłowości operacji finansowych, w szczególności poprzez wdrożenie systemu zarządzania i kontroli finansowej projektu. Problemem okazują się także procedury związane $\mathrm{z}$ przetargami obowiązujące $\mathrm{w}$ każdej uczelni. Brak wsparcia w tym zakresie, ale także niedobór np. informatyka-programisty może skutkować opóźnieniami w realizacji zadań związanych z przygotowaniem ofert, a następnie ich realizacją.

Niezależnie od tego, czy władze uczelni doceniają wysiłki bibliotekarzy w pozyskiwaniu dodatkowych funduszy, biblioteki muszą podejmować próby uzyskania środków na realizację dodatkowych działań.

W dobie konwergencji informacji, biblioteka jako pierwsza otwiera się na zmiany, najszybciej je definiuje i przygotowuje środowisko na ich przyjęcie.

Bibliotekarze aplikując o środki zewnętrzne usprawniają własny warsztat pracy, znajdują obszary do badań naukowych, uczą się korzystania z nowych technologii, ale także ratują cenne kolekcje przed zniszczeniem i udostępniają wyniki swoich prac. To wyjątkowa grupa zawodowa, która rozwijając się, pracuje na rzecz macierzystej uczelni oraz społeczności nie tylko akademickiej. Zaangażowanie w przygotowanie wniosków aplikacyjnych zmienia także postrzeganie potrzeb naukowych otoczenia oraz sposobów komunikowania się z nim. 
Dobrym kierunkiem jest włączanie bibliotekarzy w zespoły projektowe powołane przez rektorów uczelni. Uczestnicząc we wspólnym aplikowaniu o środki, bibliotekarze integrują się ze społecznością akademicką, tym samym promując usługi biblioteczne oraz potencjał własnej grupy zawodowej.

Sukces biblioteki w pozyskiwaniu środków jest zauważalny i na ogół dobrze przyjmowany przez władze uczelni. Trzeba jednak pamiętać, że ze wszystkich uzyskanych grantów, najbardziej cenione przez środowisko są granty na badania naukowe. To źródło finansowania wciąż jest niedostatecznie wykorzystywane przez pracowników bibliotek. W ostatniej dekadzie ten trend powoli się zmienia. Biblioteki działające przy dużych uczelniach stwarzają pracownikom warunki do realizacji zadań naukowych.

Warto w tym miejscu przywołać opinię dyrektora Biblioteki Uniwersyteckiej w Poznaniu dra hab. Artura Jazdona, który już w 2000 r. zauważył, że zarządzający uczelnią nie wiążą problemów nauki i szkolnictwa wyższego $\mathrm{z}$ brakiem dbałości o zapewnienie pracownikom naukowym warunków do badań i do publikowania w postaci dostępu do zasobnej $\mathrm{w}$ materiały naukowe i nowoczesne narzędzia biblioteki ${ }^{28}$. Po siedemnastu latach, które minęły od zredagowania tej opinii, niewiele się zmieniło w tym zakresie. Nadal miejscem gdzie w pierwszej kolejności ogranicza się środki jest biblioteka.

\section{Bibliografia}

1. Biblioteka Główna im. Jędrzeja Śniadeckiego AWF Warszawa. Baza naukowa Sport Polski. Tryb dostępu: http://sportpolski.awf.edu.pl/ [27 maja 2017].

2. Biblioteka Główna Uniwersytetu Ekonomicznego we Wrocławiu. Tryb dostępu: http://www.bg.ue.wroc.pl/ [27 maja 2017].

3. Biblioteka Główna Uniwersytetu Mikołaja Kopernika w Toruniu. Projekty. Tryb dostępu: http://www.bu.umk.pl/granty [27 maja 2017].

4. Biblioteka Jagiellońska Uniwersytetu Jagiellońskiego. Tryb dostępu: http:// www.bj.uj.edu.pl/dun-2015-2016 [27 maja 2017].

5. Biblioteka Uniwersytecka im. Jerzego Giedroycia w Białymstoku. Projekty. Tryb dostępu: http://bg.uwb.edu.pl/?pid=Projekty [27 maja 2017].

6. Biblioteka Uniwersytecka w Warszawie. Tryb dostępu: http://www.buw. uw.edu.pl/index.php?option=com_content $\&$ task=view\&id=2041\&Itemid=272 [27 maja 2017].

28 Zob. A. Jazdon: Finansowanie bibliotek uczelnianych. „Forum Akademickie”. Archiwum. Tryb dostępu: https://forumakademickie.pl/fa-archiwum/archiwum/2000/10/ artykuly/13.html [27 maja 2017]. 
7. Bibliotekarstwo. Pod red. A. Tokarskiej. Warszawa 2013, s. 606-607.

8. Centrum Polsko-Rosyjskiego Dialogu i Porozumienia. Tryb dostępu: http:// www.cprdip.pl/konkursy,otwarty_konkurs,edycja_2016.html [27 maja 2017].

9. Grygrowski D.: Biblioteki i pieniądze. Warszawa 2015, s. 202-206.

10. Jazdon A.: Finansowanie bibliotek uczelnianych. „Forum Akademickie”. Archiwum. Tryb dostępu: https://forumakademickie.pl/fa-archiwum/archiwum/2000/10/artykuly/13.html [27 maja 2017].

11. Jazdon A., Wojcińska M.: Zarządzanie finansami i pozyskiwanie funduszy. W: Bibliotekarstwo. Pod red. A. Tokarskiej. Warszawa 2013, s. 609.

12. Kołodziejczyk E.: Pozabudżetowe źródła finansowania bibliotek akademickich $w$ Polsce i innych krajach gospodarki wolnorynkowej. Wybrane przykłady i próba porównania. W: Pozazawodowe zainteresowania bibliotekarzy. Badania, teorie, wizje. „Biuletyn EBIB” 2005, nr 6(67). Tryb dostępu: http://www.ebib. pl/2005/67/kolodziejczyk.php [27 maja 2017].

13. Korczyńska-Derkacz M.: Nowe projekty, cenne inicjatywy i ciekawe przedsięwzięcia bibliotek naukowych. VIII Konferencja Korporacji Bibliotekarzy Wrocławskich (Wrocław, 2 grudnia 2016 r.). „Przegląd Biblioteczny” 2017, z. 1, s. 76.

14. Krasiński Z.: Wciąż nas za mało. „Forum Akademickie. Ogólnopolski miesięcznik środowisk akademickich” 2017, nr 4(281), s. 5.

15. Narodowy Program Rozwoju Humanistyki. Tryb dostępu: http://www.nauka. gov.pl/projekty-i-inicjatywy/narodowy-program-rozwoju-humanistyki.html [27 maja 2017].

16. Pismo Państwowej Jednostki Budżetowej Centrum Projektów Europejskich nr WP.425.246.2017.5AES. z dnia 9 maja 2017 r., s. 2.

17. Politechnika Wrocławska. Tryb dostępu: http://biblioteka.pwr.edu.pl/projekt-dun [27 maja 2017].

18. Rozporządzenie Ministra Nauki i Szkolnictwa Wyższego w sprawie kryteriów i trybu przyznawania oraz rozliczania środków finansowych na działalność upowszechniająca naukę. Dz.U. 2010, nr 179, poz. 1206.

19. Sprawozdanie Biblioteki Uniwersyteckiej w Toruniu za 2015 r. Tryb dostępu: http://Sprawozdanie\%20za\%20rok\%202015\%20(1).pdf [27 maja 2017].

20. Szala M.: Transkrypcje, dawnych utworów muzycznych w Bibliotece Cyfrowej Uniwersytetu Wrocławskiego. Tryb dostępu: http://www.digitalizacja.pl/Marcin-Szala/Transkrypcje-dawnych-utworow-muzycznych-w-Bibliotece-Cyfrowej-Uniwersytetu [27 maja 2017].

21. Ustawa z dnia 27 czerwca 1997 r. o bibliotekach. Dz.U. 2012, poz. 642 z późn. zm., s. 4.

22. Ustawa $z$ dnia 27 lipca 2005 r. Prawo o szkolnictwie wyższym. Dz.U. 2005, nr 164, poz. 1365 z późn. zm., s. 9, 46.

23. Ustawa $z$ dnia 30 kwietnia 2010 r. o zasadach finansowania nauki. Dz.U. 2010, nr 96, poz. 615, s. 17.

24. Wojcińska M., Wojciński D.: Fundusze strukturalne dla bibliotek w okresie programowania 2007-2013. „Biblioteka” 2009, nr 13(22), s. 111-121. Tryb dostępu: http://pressto.amu.edu.pl/index.php/b/article/viewFile/190/134 [27 maja 2017]. 